\title{
EXPORT OF DISSOLVED INORGANIC NITROGEN IN A PARTIALLY CULTIVATED SUBTROPICAL MOUNTAINOUS WATERSHED IN TAIWAN
}

\author{
SHUH-JI KAO ${ }^{1, *}$, FUH-KWO SHIAH ${ }^{2}$ and JEFFREY S. OWEN ${ }^{1}$ \\ ${ }^{1}$ Institute of Earth Sciences, Academia Sinica, Taiwan; ${ }^{2}$ Institute of Oceanography, \\ National Taiwan University, Taipei, Taiwan \\ (*authorfor correspondence,e-mail:sjkao@earth.sinica.edu.tw)
}

(Received 20 December 2002; accepted 25 January 2004)

\begin{abstract}
A spatial and temporal investigation of dissolved inorganic nitrogen (DIN; $\mathrm{NO}_{3}, \mathrm{NO}_{2}$ and $\mathrm{NH}_{4}$ ) was conducted under various water discharge conditions in Lanyang-Hsi, a subtropical mountainous stream, which drains through distinct degrees of agriculture-influenced sub-watersheds. In both the cultivated and non-cultivated sub-watersheds, $\mathrm{NO}_{3}$ was the most abundant species accounting for $>80 \%$ of total DIN, while $\mathrm{NH}_{4}$ and $\mathrm{NO}_{2}$ accounted for $<15 \%$ and $5 \%$ of DIN, respectively. Agricultural activities along the riverbank led to significantly higher $\mathrm{NO}_{3}$ concentrations $(13-246 \mu \mathrm{M})$ and DIN yields (1300-3800 $\mathrm{kg} \mathrm{N} \mathrm{km}^{-2} \mathrm{yr}^{-1}$ ) in main channel when compared to those of noncultivated tributaries (9-38 $\mu \mathrm{M}$ for $\mathrm{NO}_{3}$ and $550-740 \mathrm{~kg} \mathrm{~N} \mathrm{~km}^{-2} \mathrm{yr}^{-1}$ for yield). The much lower and less variable DIN yields observed in tributary stations (mean $=660 \pm 120 \mathrm{~kg} \mathrm{~N} \mathrm{~km}^{-2} \mathrm{yr}^{-1}$ ) are considered as the present day background of DIN yield, which is significantly higher than those of most natural watersheds in other regions. Elevated atmospheric DIN deposition is likely the cause for the high background DIN yield. Human activity within the watershed results in additional DIN yield, which accounted for $49 \%$ of total $\mathrm{N}$ export. However, the reported atmospheric DIN input in northern Taiwan $\left(\sim 1800 \mathrm{~kg} \mathrm{~N} \mathrm{~km}^{-2} \mathrm{yr}^{-1}\right)$ is much higher than the background DIN yield implying that a major fraction $(70 \%)$ of atmospheric inputs are retained or processed within the watershed. A dilution pattern occurred in the main channel where high $\mathrm{NO}_{3}$ concentrations from the upstream sources decreased significantly in downstream direction due to inputs of $\mathrm{NO}_{3}$-diluted water from non-cultivated areas. We adopted a two-source mixing model to predict the $\mathrm{NO}_{3}$ dilution pattern. This model revealed a third yet not recognized $\mathrm{N}$ source in the lower part of watershed. Model results also indicated the importance of water discharge rate in regulating the relative contribution to total DIN export among these sources.
\end{abstract}

Keywords: inorganic nitrogen, mountainous river, nitrate, subtropics, Taiwan

\section{Introduction}

From a global perspective, human activities have more than doubled the amount of nitrogen cycling in terrestrial ecosystems since the industrial revolution (Galloway et al., 1995; Vitousek et al., 1997). These increasing N inputs might result in substantial risks to various aspects for many terrestrial, fresh water and coastal ecosystems (Schindler and Bayley, 1993; Kopacek et al., 1995; Howarth et al., 1996; Vitousek et al., 1997). The impacts may become more severe in low-latitude ecosystems relative to those occurring in temperate zones (Downing et al., 1999);

Water, Air, and Soil Pollution 156: 211-228, 2004.

(c) 2004 Kluwer Academic Publishers. Printed in the Netherlands. 
however, patterns in nutrient fluxes in low-latitude ecosystems are often less well documented than those for ecosystems in higher latitudes.

Oceania islands in the tropics and subtropics are characterized by mountainous watersheds, high precipitation and high water runoff, which collectively accounts for $12 \%$ of the global water discharge (Meybeck et al., 1989; Milliman, 1991). Rates of $\mathrm{N}$ cycling in tropical and subtropical watersheds may differ from that in temperate regions; but there have been far few studies focusing on $\mathrm{N}$ biogeochemistry than in temperate areas (Matson et al., 1999). Moreover, 2/3 of energy-related $\mathrm{N}$ emissions are expected to occur in lower latitude regions by the year 2020 (Galloway et al., 1994). Estimating contemporary $\mathrm{N}$ fluxes and understanding their controlling factors is thus one of the urgent tasks to undertake in order to expand our knowledge of watershed function in tropical and subtropical watersheds.

Taiwan is a subtropical mountainous island, $160 \mathrm{~km}$ off the southeast coast of mainland China (Figure 1a). China is now a major source of atmospheric pollutants for adjacent countries (Bashkin and Park, 1998). Previous reports have indicated that atmospheric DIN deposition in Taiwan ranges from 1400 to $2300 \mathrm{~kg} \mathrm{~N} \mathrm{~km}^{-2} \mathrm{yr}^{-1}$ (Figure 1b; King et al., 1994; Chen et al., 1998; Lin et al., 2000), and presumably results from both local emissions and long-range atmospheric transport (Bashkin and Park, 1998). DIN inputs to Taiwan are higher than inputs to most regions in unpolluted areas of Europe (Parker, 1983), North America and Japan (generally $<1500 \mathrm{~kg} \mathrm{~N} \mathrm{~km}^{-2} \mathrm{yr}^{-1}$; Ohrui and Mitchell, 1997) and areas of similar latitudes

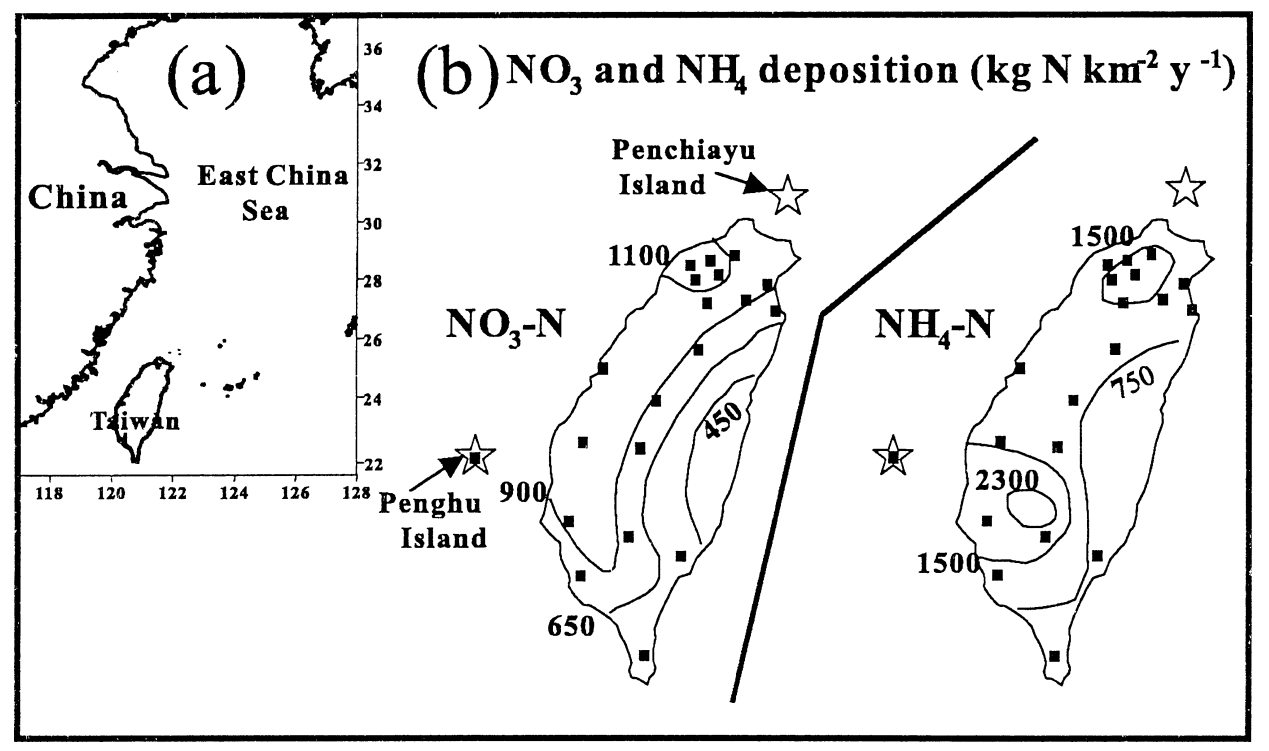

Figure 1. (a) Study site location. (b) Contour map of atmospheric $\mathrm{NO}_{3}-\mathrm{N}$ (left) and $\mathrm{NH}_{4}-\mathrm{N}$ (right) deposition around Taiwan (modified from Chen et al., 1998). Values are deposition rates in $\mathrm{kg} \mathrm{N} \mathrm{km}^{-2}$ $\mathrm{yr}^{-1}$. Filled squares are gauging stations for rainwater chemistry. The stars mark two remote islands. 
(Prospero et al., 1996). In addition, local agricultural activities likely supply additional amounts of nitrogen that can be transported to surface waters and coastal areas. Numerous studies have recognized the importance of assessing and modeling the influence of agricultural activities on nutrient inventories and exports in watersheds (Mason et al., 1990; Kronvang et al., 1995; Pekarova and Pekar, 1996). Multi-scale (i.e., local and regional scales) anthropogenic factors in Taiwanese watersheds have likely altered the natural patterns in $\mathrm{N}$ cycling and thus offer us an opportunity to explore how subtropical watersheds might respond to future changes. This paper presents the results of the first study in Taiwan that we are aware of, to investigate spatial and temporal variation of dissolved inorganic nitrogen (DIN) concentrations in a mixed land use watershed in Taiwan. The objectives were: (1) to quantify the effects of local agricultural activity on DIN speciation and flux, (2) to estimate background (relatively pristine conditions) of DIN yield and (3) to assess retention of inorganic nitrogen in the Lanyang-Hsi watershed.

\section{Materials and Methods}

\subsection{STUDY AREA}

The Lanyang-Hsi River (Figure 2a) is located in I-Lan County. The basement rocks are mainly tertiary argillite-slate and metasandstone (Ho, 1975). The narrow and long Lanyang-Hsi basin is a subtropical mountainous watershed extending from an elevation of $3535 \mathrm{~m}$ to the east coast of Taiwan with a length of $64 \mathrm{~km}$ (Figure 2a). The main channel flows southwest-northeast with a mean gradient of $1 / 21$ while tributaries have much steeper slopes joining the main channel from both sides.

The annual rainfall ranges from 2500 to $3500 \mathrm{~mm} \mathrm{yr}^{-1}$ over the entire watershed with a mean of $3000 \mathrm{~mm} \mathrm{yr}^{-1}$ (Taiwan Hydrological Yearbooks). The dry season is usually from April to June. During summer (late June to September), tropical storms (typhoons) cause torrential rain, which accounts for $38 \%$ of the annual rainfall on average. From late September to the end of March of the next year, the northeast monsoon brings rainfall, which accounts for $45 \%$ of the total annual rainfall. The sudden increase in discharge induced by typhoon is more than two orders of magnitude higher than the baseflow during the dry season.

The annual mean runoff (water discharge over the area above the lowest part of the watershed; St. \#8) is estimated to be $2100 \mathrm{~mm} \mathrm{yr}^{-1}$, indicating that $70 \%$ of the annual precipitation flows through gauging St. \#8 as surface runoff (Water Resources Agency, Taiwan). This high runoff to precipitation ratio suggests a short residence time for water in this watershed. A 50-year hydrological record at St. \#8 shows that water discharge rate ranges from $0.3 \mathrm{~mm} \mathrm{~d}^{-1}$ to a historical maximum of $330 \mathrm{~mm} \mathrm{~d}^{-1}$ with most values (>99\%; Taiwan Hydrological Yearbooks) $<100 \mathrm{~mm}$ $\mathrm{d}^{-1}$ (see Figure 5b). Generally speaking, the whole watershed is well drained due to steep slopes. 


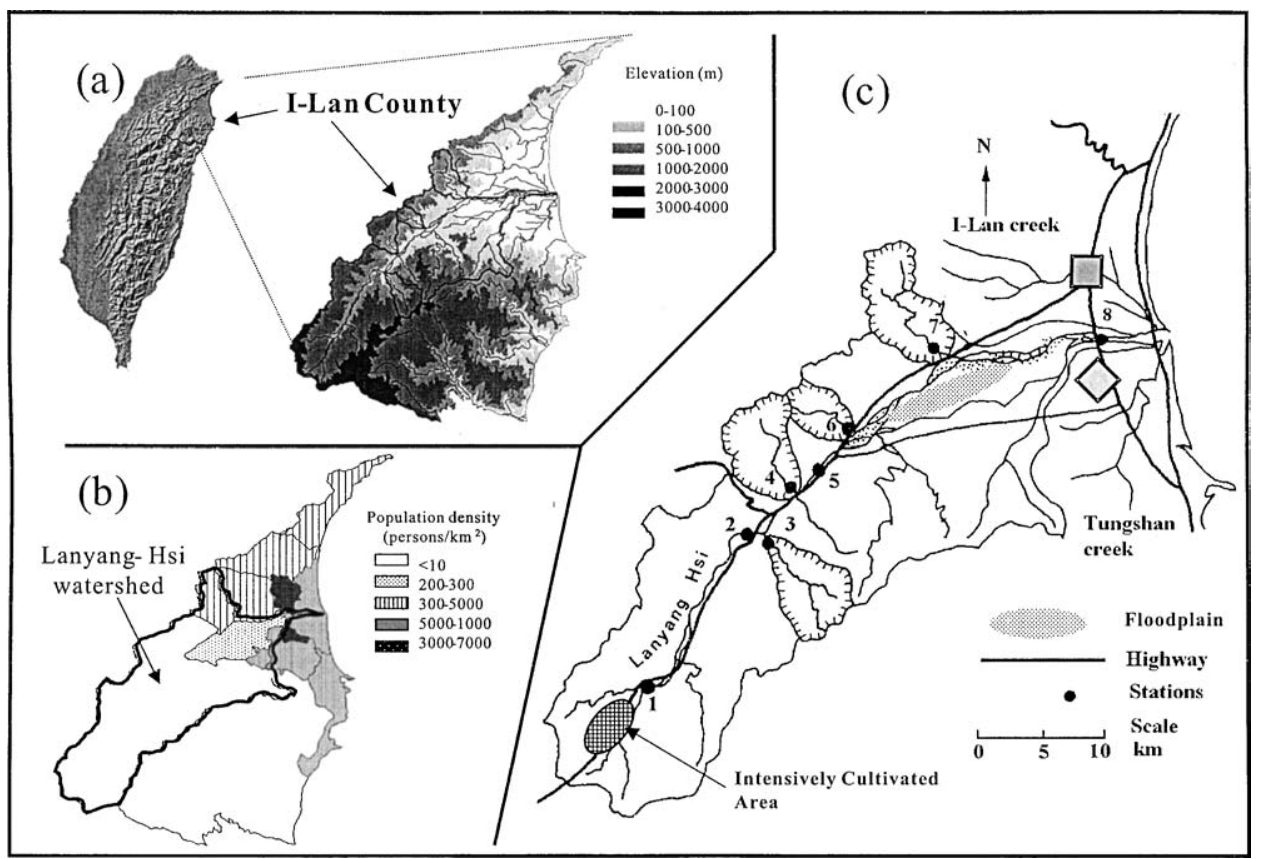

Figure 2. Map of I-Lan County and Lanyang-Hsi for (a) topography and drainage systems, (b) population density and (c) sampling stations. Bold curves in (a) and (b) represent the boundaries of studied watershed and sub-watersheds. I-Lan and Loutong cities are marked by a square and diamond, respectively. Solid circles and attached numbers represent stations. The upstream agricultural area and lower reach floodplain are also marked.

The population density is unevenly distributed in I-Lan County ranging from less than 10 persons to over 3000 persons $\mathrm{km}^{-2}$ (Figure 2b). Two tributaries, I-Lan and Tungshan creek, drain through I-Lan and Loutong cities (Figure 2c), respectively, where high population densities occur. The monitored watershed was $820 \mathrm{~km}^{2}$ in size above St. \#8, which excludes two urban-influenced sub-watersheds that join the main channel at the river mouth (Figure 2c). Most areas of the studied watershed have a population density of less than 8 persons $\mathrm{km}^{-2}$.

Over $95 \%$ of the watershed area is forested. The typical overstory vegetation consists of broadleaf evergreen species such as Castanopis carlesii, Machilus thunbergii, and Engelhardia roxburghiani (Goan and Chen, 1995). Almost all farming activities are concentrated on the riverbank and floodplain along the main channel due to road availability (Figure 2c). Some intensive agricultural activity occurs in the area above St. \#1 at an elevation above $850 \mathrm{~m}$ (Figure 2c). In this area, mountain vegetables, such as cabbage, are usually planted. In the middle-lower reach below St. \#5, the major floodplain (Figure 2c), small-scale fruit orchards have been established.

Previous studies indicated that farming activities in the main channel result in high total suspended matter (TSM) concentrations during all seasons (Kao and Liu, 
1996, 2002). After torrential rains, TSM concentration in the main channel can reach thousands $\mathrm{mg} \mathrm{L}^{-1}$, which is more than three orders of magnitude higher than those in the tributaries observed at the same sampling day. In addition, the highest TSM concentration was always observed at St. \#1, suggesting that exacerbation of soil erosion resulted from intensive agricultural activities (Kao and Liu, 2000, 2002).

\subsection{SAMPLING AND ANALYSES}

Water samples were taken from eight stations without tidal influence (Figure 2c); four stations (Sts. \#1, \#2, \#5, \#8) were along the main channel and four others Sts. \#3, \#4, \#6 and \#7) were located at the outlet of four tributaries. Sampling was conducted eight times at all stations in different seasons covering a wide range of water runoff $\left(\sim 1-100 \mathrm{~mm} \mathrm{~d}^{-1}\right)$, twice in May and August 1994 and six times between September 1998 and March 1999. Water samples were filtered through GF/F filters immediately after collection. The filtrate were quick-frozen in liquid nitrogen and then kept in an ice chest during transport. The frozen samples were thawed and concentrations of nitrite $\left(\mathrm{NO}_{2}\right)$ and nitrate $\left(\mathrm{NO}_{3}\right)$ were measured using colorimetric methods. Nitrate was reduced to nitrite with a cadmium wire, which was activated with a copper sulfate solution, and the nitrite was converted to pink azo dye for colorimetric determination with a detection limit of $0.2 \mu \mathrm{M}$ (Pai et al., 1990). Ammonium $\left(\mathrm{NH}_{4}\right)$ was determined by the indophenol blue method (Strickland and Parsons, 1972) with a detection limit of $0.1 \mu \mathrm{M}$.

\subsection{ESTIMATION OF DIN YIELDS AND FLUXES}

To estimate the DIN yield, we used a Flow-Duration Rating-Curve method. The rating curve depicts the empirical relationship between daily DIN yield $(Y, \mathrm{~kg} \mathrm{~N}$ $\left.\mathrm{km}^{-2} \mathrm{~d}^{-1}\right)$ and daily runoff $\left(Q, \mathrm{~mm} \mathrm{~d}^{-1}\right)$. The daily runoff was derived by averaging the volume of water discharge by the respective drainage area at St. \#8. Daily DIN yield is the product of measured DIN concentration and daily runoff. The function $Y(Q)=10^{k} * Q^{b}$, where $k$ and $b$ are the rating coefficient and exponent, can be determined using log-log linear regression and back transformation. After we established the rating curves (shown in Table I), we obtained $Y_{i}$ from any given $Q_{i}$ for each station. Within a given period, the mean DIN yield $\left(Y_{\text {mean }}\right)$ was expressed as:

$$
Y_{\text {mean }}=\sum_{i=Q_{\min }}^{Q_{\max }} Y\left(Q_{i}\right) p\left(Q_{i}\right),
$$

where $p(Q)$ is the probability distribution of $Q$. (Figure $5 \mathrm{~b}$; data from Taiwan Hydrological Yearbooks, 1980-95). Based on Equation (1) we estimated the mean DIN yield on annual basis. The uncertainty was estimated from the mean relative deviations between the observed and the calculated values of the daily loadings. 
TABLE I

The regression functions for DIN yield to runoff depth $(n=8)$

\begin{tabular}{lll}
\hline Stations & Regression function & $R^{2}$ \\
\hline 1 & $Y=0.296 * Q^{1.55}$ & $0.99(p<0.01)$ \\
2 & $Y=0.229 * Q^{1.46}$ & $0.99(p<0.01)$ \\
5 & $Y=0.219 * Q^{1.35}$ & $0.97(p<0.01)$ \\
8 & $Y=0.522 * Q^{1.05}$ & $0.98(p<0.01)$ \\
3 & $Y=0.269 * Q^{1.05}$ & $0.98(p<0.01)$ \\
4 & $Y=0.130 * Q^{1.23}$ & $0.99(p<0.01)$ \\
6 & $Y=0.140 * Q^{1.28}$ & $0.99(p<0.01)$ \\
7 & $Y=0.161 * Q^{1.25}$ & $0.98(p<0.01)$ \\
\hline " $Y$ " is in kg N km ${ }^{-2} \mathrm{~d}^{-1}$ and “ $Q$ " represents the runoff depth \\
per day $\left(\mathrm{mm} \mathrm{d}^{-1}\right)$.
\end{tabular}

Annual DIN flux for individual station was then calculated as $Y_{\text {mean }}$ times the drainage area above the respective station.

\subsection{TWO-SOURCE MIXING MODEL}

A two-source mixing model was adopted to simulate the dilution of $\mathrm{NO}_{3}$ (see below) in the main channel under various water discharge conditions. In this model, the two sources considered are the diffuse source (background tributaries) and the agriculture source (cultivated watershed above St. \#1).

There were two assumptions in this model. The first assumption was that the volume of water discharge in the main channel increased proportionally as the drainage area increased cumulatively downstream. This assumption has been validated previously (Kao and Liu, 1996) by examining the water discharge rate (per unit area) recorded at gauging St. \#2 and St. \#8 for the record available (20 yrs). The second assumption was that $\mathrm{NO}_{3}$ behaved conservatively in the main channel (i.e. no biogeochemical processes occurred). This assumption is appropriate for Lanyang-Hsi (with exceptions during low flow), especially during periods of high surface runoff (see section on 'Discussion'). Primary productivity in the water column of the main channel is low $\left(<3 \mathrm{mg} \mathrm{C} \mathrm{m}^{-3} \mathrm{~d}^{-1}\right)$ due to high turbidity (Shiah et al., 1996). We assumed that $\mathrm{NO}_{3}$ depletion due to denitrification in surface sediments was not too important since the organic carbon contents were very low $(<0.4 \%$; Kao and Liu, 2000) in channel sediments. In addition, the short distance $\left(<50 \mathrm{~km}\right.$ from St. \#1 to St. \#8) and high flow velocity $\left(>1 \mathrm{~m} \mathrm{~s}^{-1}\right.$ in most sections) lead to a short travel time ( $<1$ day) for water parcel traveling through the channel. Consequently, denitrification was neglected in the model.

In this model, the expression regarding the water balance is:

$$
Q_{1}+Q_{\mathrm{b}}=Q_{\mathrm{c}}
$$


where $Q_{\mathrm{c}}$ is the cumulative water flux in the main channel. $Q_{1}$ represents the water flux gauged at the upstream St. \#1 and $Q_{\mathrm{b}}$ represents the down stream water flux input from areas other than St. 1. $Q_{\mathrm{c}}$ increases proportionally with the increasing of drainage area. The second equation describing the $\mathrm{NO}_{3}$ mass balance is:

$$
Q_{1} \times\left[\mathrm{NO}_{3}\right]_{1}+Q_{\mathrm{b}} \times\left[\mathrm{NO}_{3}\right]_{\mathrm{b}}=Q_{\mathrm{c}} \times\left[\mathrm{NO}_{3}\right]_{\mathrm{c}}
$$

where $\left[\mathrm{NO}_{3}\right]_{1}$ is the $\mathrm{NO}_{3}$ concentration measured at $\mathrm{St}$. $\# 1$ and $\left[\mathrm{NO}_{3}\right]_{\mathrm{b}}$ is the background value of $\mathrm{NO}_{3}$, which is the mean concentration observed at the four tributaries on the same sampling day. The drainage areas above Sts. \#1, \#2, \#5 and \#8 were $10 \%, 30 \%, 52 \%$ and $100 \%$, respectively. Based on our first assumption, the known area percentages therefore replace the absolute volume of water flux to estimate the $\mathrm{NO}_{3}$ mass balances. These two equations were then combined:

$$
A_{1} \% \times\left[\mathrm{NO}_{3}\right]_{1}+\left(A_{\mathrm{c}} \%-A_{1} \%\right) \times\left[\mathrm{NO}_{3}\right]_{\mathrm{b}}=A_{\mathrm{c}} \% \times\left[\mathrm{NO}_{3}\right]_{\mathrm{c}} .
$$

Since $\left[\mathrm{NO}_{3}\right]_{1}$ and $\left[\mathrm{NO}_{3}\right]_{\mathrm{b}}$ were measured and $\mathrm{A}_{1}$ is a constant, the value of $\left[\mathrm{NO}_{3}\right]_{\mathrm{c}}$ at any location in the main channel can therefore be predicted by its cumulative watershed area $\left(A_{\mathrm{c}}\right)$. The $\left[\mathrm{NO}_{3}\right]$ concentrations observed at Sts. \#2, \#5 and \#8 can therefore be used to check the usefulness of the two-source mixing model.

\section{Results}

During the sampling period, the highest water runoff was observed on September 28 1998, which was two days after a typhoon invasion (Figure 3a). The lowest water runoff occurred during March 1999, which marked the beginning of the dry season. For all but $\mathrm{St}$. \#8, $\mathrm{NO}_{3}$ concentrations varied concomitantly with water discharge rates and were the highest during a typhoon event (Figure 3b) demonstrating that higher discharge results in higher concentrations and consequently larger export of nutrients in all stations including cultivated and non-cultivated areas. $\mathrm{NO}_{3}$ concentrations observed in the main channel (Sts. \#1, \#2, \#5, \#8) range from 13 to $247 \mu \mathrm{M}$, which were almost always higher than those observed in the tributaries (Sts. \#3, \#4, \#6, \#7; Figure 3b) with a range of 9-38 $\mu \mathrm{M}$. This contrasting pattern resembles previously reported spatial distribution of TSM in Lanyang-Hsi (Kao et al., 1996). The correspondingly high TSM and $\mathrm{NO}_{3}$ concentrations might imply that the higher $\mathrm{NO}_{3}$ concentrations are associated with soil erosion resulting from agricultural activities along the main channel.

During the same sampling day, the highest $\mathrm{NO}_{3}$ concentration was almost always observed at $\mathrm{St}$. \#1 (Figure 3b) followed by a significant decrease in $\mathrm{NO}_{3}$ concentration downstream in the main channel (Figures 4a, 6a-6d). This dilution pattern is apparently attributed to the higher $\mathrm{NO}_{3}$ concentration water from upstream St. \#1 and lower $\mathrm{NO}_{3}$ concentration water input from the non-cultivated downstream tributaries. In the main channel, the variability of $\mathrm{NO}_{3}$ concentration was much larger 

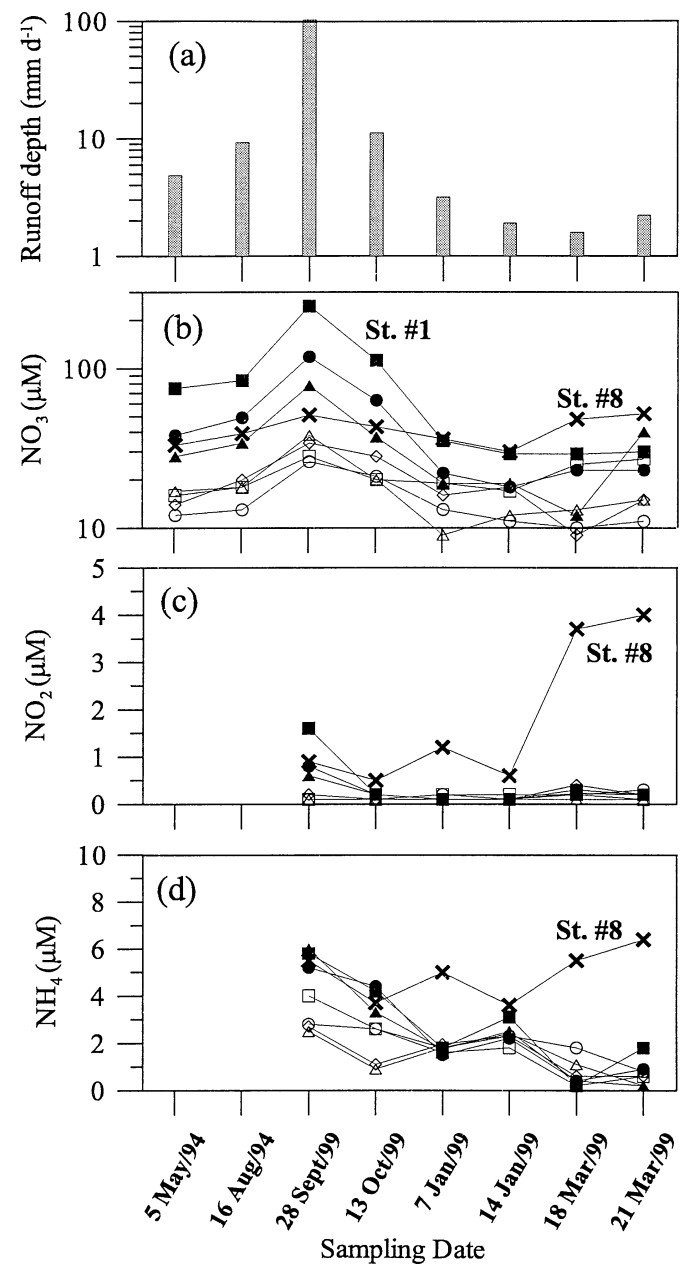

Figure 3. Variations of (a) water runoff, and concentrations of (b) $\mathrm{NO}_{3}$, (c) $\mathrm{NO}_{2}$ and (d) $\mathrm{NH}_{4}$ on

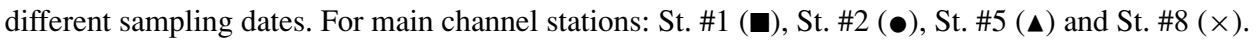

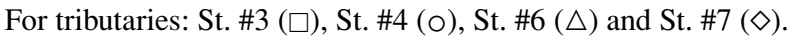

in the upstream station relative to downstream stations (Figure 4a). Compared to stations in the main channel, the tributary stations showed a narrower range of $\mathrm{NO}_{3}$ concentrations. The degree of variability likely reflects the $\mathrm{NO}_{3}$ leaching potential and the influence of human disturbance through land use activities. Therefore, the $\mathrm{NO}_{3}$ concentrations in the tributaries can be considered as a type of 'background' condition in Lanyang-Hsi. This background concentration of $\mathrm{NO}_{3}(9-38 \mu \mathrm{M}$ with a mean value of $18 \pm 7$ ) is slightly higher than the reported ranges $(4-14 \mu \mathrm{M})$ for a variety of unpolluted streams and rivers (Meybeck, 1993; Lewis et al., 1999). Coupled with higher water runoff, the nitrogen yield is high (see below). Our results showed that hydrologic conditions and agricultural activity are two major factors determining the spatial distribution of $\mathrm{NO}_{3}$ in river water within the watershed. 

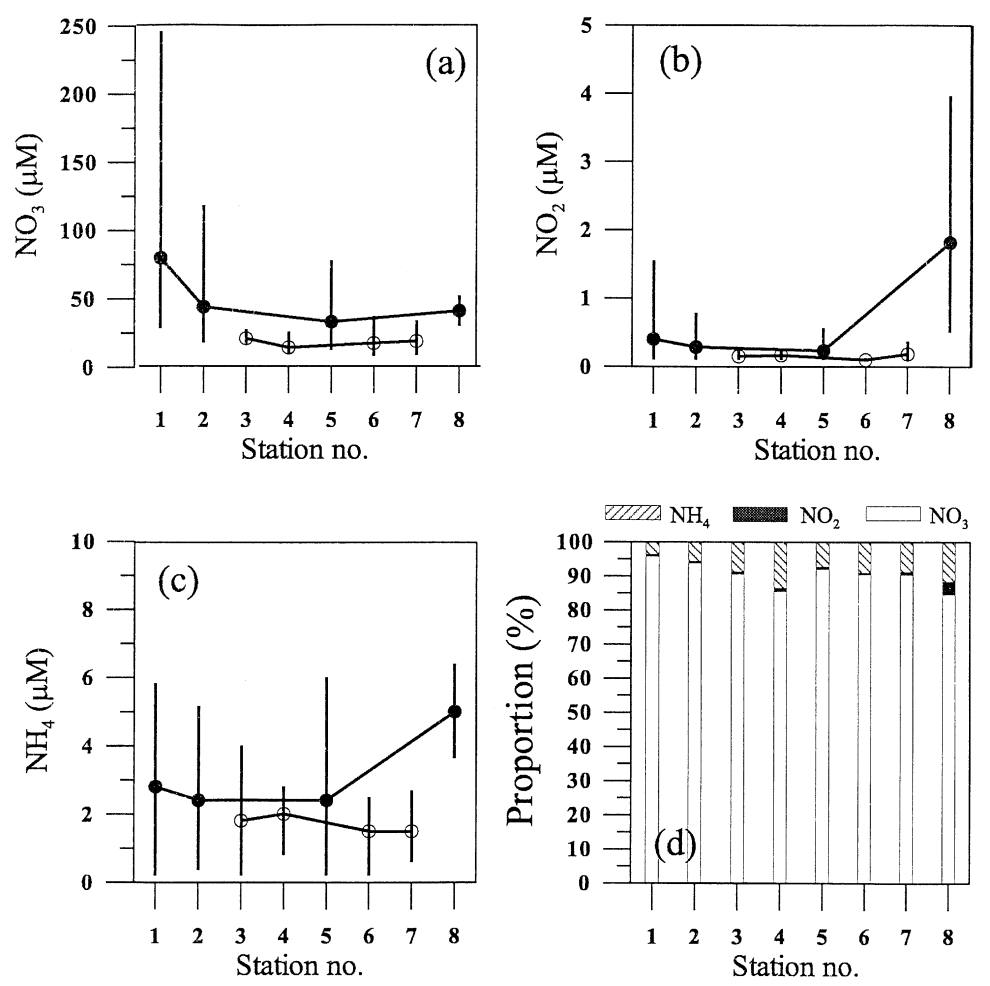

Figure 4. Spatial variation of (a) $\mathrm{NO}_{3}$, (b) $\mathrm{NO}_{2}$ and (c) $\mathrm{NH}_{4}$ and (d) the proportion of three species in total dissolved nitrogen. In (a), (b) and (c), the solid and open dots represent the mean values for main channel and tributary stations, respectively. The vertical bar indicates the range of measurements.

$\mathrm{NO}_{2}$ concentrations ranged from 0.1 to $4 \mu \mathrm{M}$ with most observations close to the detection limit. $\mathrm{NH}_{4}$ concentrations $(0.1-6 \mu \mathrm{M}$; Figures $3 \mathrm{~d}$ and $4 \mathrm{c})$ were slightly higher than those of $\mathrm{NO}_{2}$ but their patterns were similar to each other. Both $\mathrm{NO}_{2}$ and $\mathrm{NH}_{4}$ concentrations varied concomitantly with water runoff (Figures $3 \mathrm{c}$ and 3d), except for St. \#8. Note that $\mathrm{NH}_{4}$ and $\mathrm{NO}_{2}$ at $\mathrm{St}$. \#8 showed the opposite trend with discharge (Figures. 3c and 3d). Because St. \#8 was located at the furthest point downstream, the consistently high $\mathrm{NH}_{4}$ and $\mathrm{NO}_{2}$ concentrations observed at St. \#8 (Figures $4 \mathrm{~b}$ and $4 \mathrm{c}$ ) might indicate a local source input in the intermediate floodplain between St. \#5 and St. \#8. This source likely plays a role in regulating the DIN speciation and concentration at St. \#8, and its role becomes important during low discharge periods.

Overall, $\mathrm{NO}_{3}$ comprised $\sim 85-95 \%$ of total DIN, and $\mathrm{NH}_{4}$ and $\mathrm{NO}_{2}$ comprised $<15 \%$ and $5 \%$ of total DIN, respectively (Figure $4 \mathrm{~d}$ ). $\mathrm{NO}_{3}$ is the major leachable DIN form in cultivated systems although various ammonium salts are major fertilizers that are applied within the cultivated area. This phenomenon is consistent with other observations (e.g. Burt et al., 1988; Jordan et al., 1997). As shown in Figure 1, we noted that more than 50\% of the atmospheric DIN deposition is 

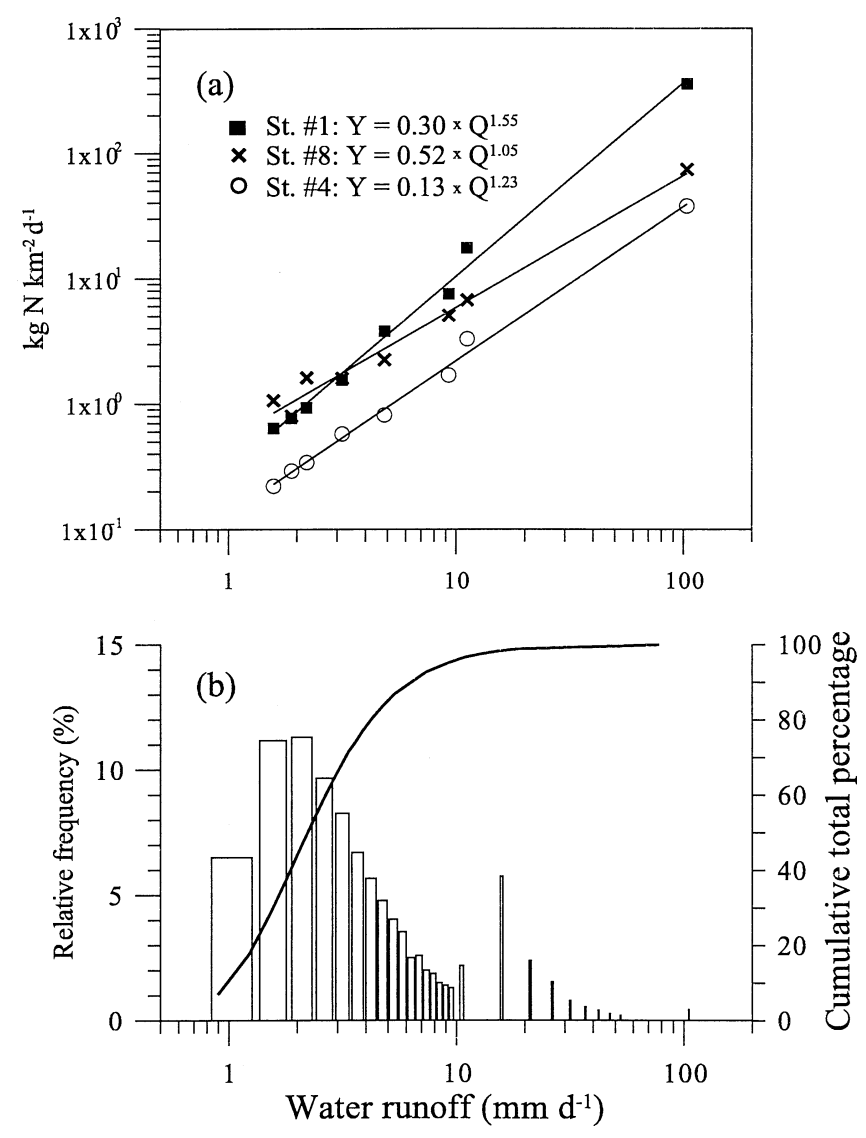

Figure 5. (a) Three examples of scatter plots showing DIN yield and water runoff ( $\mathrm{mm} \mathrm{d}^{-1}$ ). Equations are shown. (b) The frequency distribution of water runoff recorded for the period of 1980-95. Curve represents the cumulative total percentage.

$\mathrm{NH}_{4}-\mathrm{N}$. The low concentrations of $\mathrm{NH}_{4}$ in river water observed under various water discharge conditions indicated that the atmospheric derived $\mathrm{NH}_{4}$ is transformed to other nitrogen forms within the watershed system.

The DIN concentration and water runoff are positively correlated (not shown) resulting in positive relationships between DIN yields and water runoff for all stations (Table I and Figure 5a). Three examples of rating curves, which differ from each other, are shown in Figure 5a. This positive correlation illustrates the flushing nature of DIN export from this system. Previous study in Lanyang-Hsi (Kao, 1995) indicated that DIN concentration decreased during flood peak flows as reported by Prochazkova and Brink (1991). However, the duration of this phenomenon is only several hours and the dropdown is $<20 \%$ compared to the peak concentration (Kao, 1995). Since the daily runoff varies over two orders of magnitude while DIN concentration varies within a much smaller range (factors of $<4$ for tributaries and $<8$ for the main channel stations), the DIN flux is apparently determined by 
TABLE II

Estimation of human-induced DIN fluxes through main channel stations

\begin{tabular}{|c|c|c|c|c|}
\hline Station No. & $\begin{array}{l}\text { (A) } \\
\text { Area }\left(\mathrm{km}^{2}\right)\end{array}$ & $\begin{array}{l}\text { (B) DIN yield } \\
\left(\mathrm{kg} \mathrm{N} \mathrm{km}^{-2} \mathrm{yr}^{-1}\right)\end{array}$ & $\begin{array}{l}\text { (C) })^{\mathrm{a}} \text { Background yield } \\
\left(\mathrm{kg} \mathrm{N} \mathrm{km}^{-2} \mathrm{yr}^{-1}\right)\end{array}$ & $\begin{array}{l}\text { (D) }{ }^{\mathrm{b}} \text { Human-induced } \\
\text { flux (ton } \mathrm{N} \mathrm{yr}^{-1} \text { ) }\end{array}$ \\
\hline 1 & 82 & $3800 \pm 570$ & $660 \pm 120$ & $257 \pm 57$ \\
\hline 2 & 246 & $2100 \pm 350$ & $660 \pm 120$ & $354 \pm 115$ \\
\hline 5 & 426 & $1400 \pm 380$ & $660 \pm 120$ & $315 \pm 214$ \\
\hline 8 & 820 & $1300 \pm 230$ & $660 \pm 120$ & $525 \pm 287$ \\
\hline
\end{tabular}

${ }^{a}$ Background yield is derived from averaging DIN yields from four tributary stations.

${ }^{\mathrm{b}}(\mathrm{D})=[(\mathrm{B})-(\mathrm{C})] \cdot(\mathrm{A})$.

runoff rather than the variability of concentration. The rating curve relationship (Table I) for each station was highly significant $\left(R^{2}>0.97 ; p<0.01\right)$ suggesting that we can reasonably estimate $Y_{\text {mean }}$ by using daily runoff depth $\left(\mathrm{mm} \mathrm{d}^{-1}\right)$. In addition, our wide sampling range of water discharge (Figure 5) allowed an estimated $Y_{\text {mean }}$ without significantly extrapolating the water runoff rates. The largest rating exponent (1.55; Table I) was found at St. \#1, indicating that the DIN yield of St. \#1 may increase much more dramatically as the runoff increases due to the non-linear effect since the regressions are as power-law functions. The largest exponent at St. $\# 1$ is related to the largest variability of $\mathrm{NO}_{3}$ concentration among of all stations.

The annual $Y_{\text {mean }}$ for Sts. \#1, \#2, \#5 and \#8 in the main channel were estimated to be $3800 \pm 570,2100 \pm 350,1400 \pm 380$ and $1300 \pm 230 \mathrm{~kg} \mathrm{~N} \mathrm{~km}^{-2} \mathrm{yr}^{-1}$, respectively (shown in Table II). While for Sts. \#3, \#4, \#6 and \#7 in the tributaries, the values of $Y_{\text {mean }}$ were $670 \pm 130,700 \pm 90,550 \pm 110$ and $740 \pm 160 \mathrm{~kg} \mathrm{~N} \mathrm{~km}^{-2}$ $\mathrm{yr}^{-1}$, respectively. The much higher DIN yields for stations in the main channel are apparently induced by local agricultural activities. Compared to those of the main channel stations the $Y_{\text {mean }}$ values among the tributary stations did not vary greatly.

\section{Discussion}

\subsection{BACKGROUND AND HUMAN-INDUCED DIN YIELDS OF SUB-WATERSHEDS}

The mean yield $\left(660 \pm 120 \mathrm{~kg} \mathrm{~N} \mathrm{~km}^{-2} \mathrm{yr}^{-1}\right)$ for the tributaries, which are pristine and not influenced by land use, is considered as the background DIN yield (Table II). The additional portion above the background DIN yield is then considered to be the human-induced DIN yield. The human-induced DIN flux (Table II) can be obtained for each sub-watershed by multiplying the DIN increment at each station by their respective drainage area $\left(A_{i}\right)$. The resulting human-induced fluxes for the four main channel stations from St. \#1 to St. \#8 were 257, 354, 315 and 525 ton $\mathrm{N} \mathrm{yr}^{-1}$, respectively. Obviously, the human-induced DIN fluxes increase in the downstream direction indicating that the net DIN input from human activities accumulates through the main channel even though DIN concentrations are reduced. 
The human-induced DIN fluxes show a significant increase from St. \#5 to St. \#8, revealing that an additional DIN source should exist between St. \#5 and \#8, though we do not know the type of this $\mathrm{N}$ source. This source was also indicated by higher concentrations of $\mathrm{NO}_{2}$ and $\mathrm{NH}_{4}$ observed at St. \#8.

Similarly, the annual total DIN export for entire watershed above St. \#8 was estimated to be 1070 ton $\mathrm{N} \mathrm{y}^{-1}$. The background diffuse source was apparently the major contributor to the DIN export accounting for $51 \%$ of the annual DIN export. The remaining $49 \%$ was probably induced by anthropogenic activities, the upstream agriculture input (area above St. \#1) accounted for $24 \%$ and the lower reach unidentified source (mostly from floodplain below St. \#5) contributed the remaining $25 \%$ of the total export. Some plausible sources, such as the agricultural activity (fertilizer use), sewage input and groundwater $\mathrm{N}$ input (as mentioned by Mason et al., 1990), on the lower reach floodplain were not considered in our model, and might account for the unidentified source. Unfortunately, no data regarding groundwater seepage, fertilizer use, and sewage inputs are available for LanyangHsi. Further studies are needed to quantify $\mathrm{N}$ sources and relevant hydrological or biogeochemical processes in the Lanyang-Hsi watershed better.

\subsection{COMPARISON BETWEEN SIMULATION AND OBSERVATION}

Most observed values of DIN concentrations at Sts. \#2 and \#5 fitted the model predictions well (Figures 6a-6g) except for March 18, 21, 1999 (Figures 6g-6h). This suggests that the mixing model was applicable for the mid- to up-stream watershed area above St. \#5. During high discharge periods, the simulated data fitted well for observations at St. \#8 (Figures 6a-6d). The agreement between observations and simulations implies that the two assumed $\mathrm{N}$ sources were the most important contributors in regulating the spatial patterns in $\mathrm{NO}_{3}$ concentrations in the main channel above St. \#5. In contrast, during low discharge periods, the predicted DIN concentrations for St. \#8 were lower than the observed values (Figures 6e-6h), resulting from floodplain source input.

In the main channel, except St. \#8, there were only two exceptions where the simulated data did not compare well with the observations. This occurred at St. \#5, where $\mathrm{NO}_{3}$ concentrations were lower than the predicted values and even below the background value (solid line in Figure 6). Such case only occurred during the dry period (Figures $6 \mathrm{~g}-6 \mathrm{~h}$ ), implying that our second assumption regarding conservative behavior of $\mathrm{NO}_{3}$ in the main channel might not be appropriate during dry periods. Biological uptake might be responsible for the $\mathrm{NO}_{3}$ depletion observed at St. \#5. Lower flow velocity during low water discharge period (i.e., longer travel time) coupled with sediment deposition induced by a decrease in channel slope (Kao and Liu, 1996, 2002) may lead to detectable biological removal of $\mathrm{NO}_{3}$. Overall, our model successfully predicted $\mathrm{NO}_{3}$ concentrations at the upper and middle sections when water discharge was greater than $\sim 4 \mathrm{~mm} \mathrm{~d}^{-1}$. 

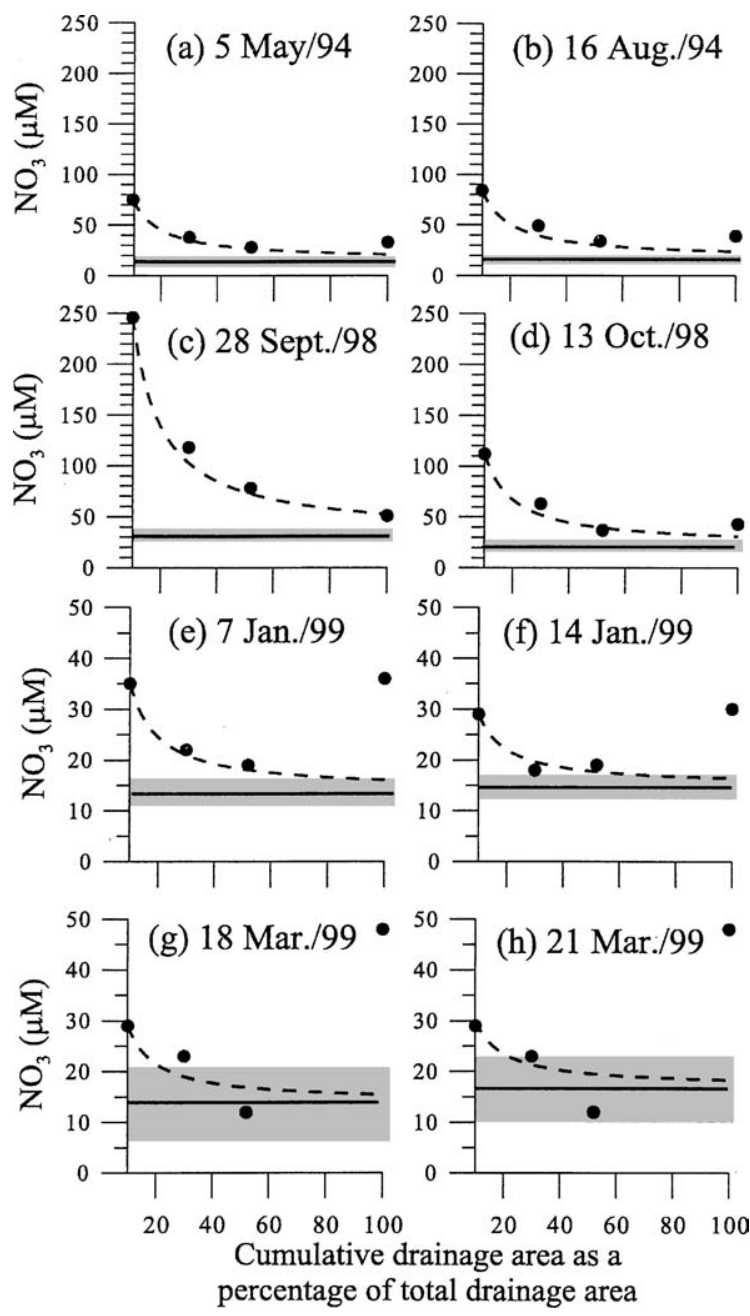

Figure 6. Model prediction and observed concentrations for different sampling dates. Note that the axes have different scales in (a)-(d) and (e)-(h). Dashed curves indicate the predicted concentration ( $C_{\text {predicted }}$, see the text). The solid line represents the background level of $\mathrm{NO}_{3}$ concentration derived by averaging the $\mathrm{NO}_{3}$ concentrations from four tributaries $\left(C_{\text {background }}\right)$. The filled dots are the observed values $\left(C_{\text {observed }}\right)$. Gray areas represent the range of $\mathrm{NO}_{3}$ concentration measured at four tributary stations.

\subsection{WATER DISCHARGE INFLUENCE ON PROPORTIONAL CONTRIBUTIONS OF N SOURCES}

The observed $\mathrm{NO}_{3}$ concentration $\left(C_{\text {observed }}\right.$, filled dots in Figure 6$)$ at the outlet St. \#8 represents the terminal composition contributed from all three sources with mixed ratio, which might change as the water discharge rate changes. Based on our modeling results under different water discharge, we discuss the effect of water 


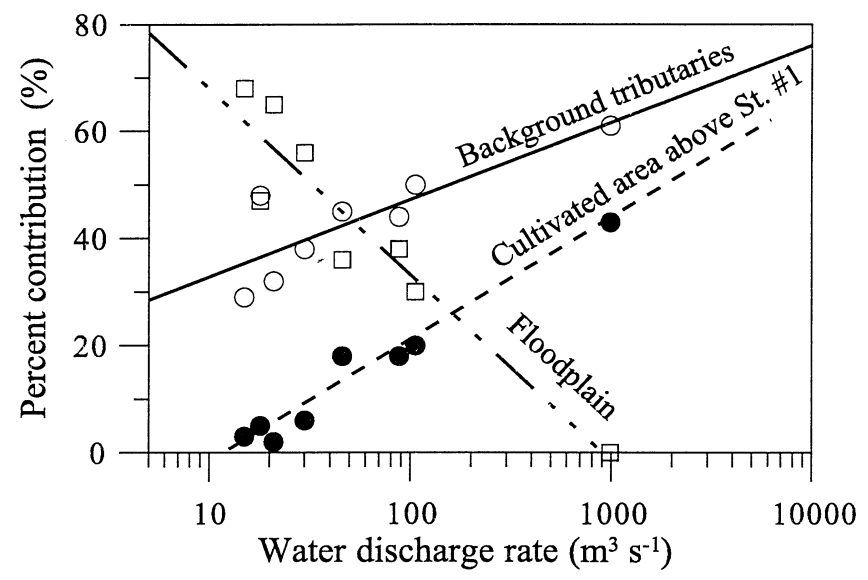

Figure 7. Relationship between water discharge and the contribution percentage (\%) from three sources to daily $\mathrm{NO}_{3}$ export: cultivated area above St. \#1 $(\bullet)$, background tributaries (०) and area below St. \#5 ( $\square$ ).

runoff on the proportional contribution from three sources to daily $\mathrm{NO}_{3}$ export. At St. \#8, there are three values on each sampling day in the order: $C_{\text {observed }}>$ $C_{\text {predicted }}>C_{\text {background }}$ (see Figure 6). $C_{\text {background }}$ is the background concentration (solid line in Figure 6). The contribution percentage from background source can be obtained by dividing $C_{\text {background }}$ by $C_{\text {observed }}$. Similarly, the difference between $C_{\text {predicted }}$ and $C_{\text {background }}$ can be regarded as the contribution from the area above St. $\# 1$. The difference between the observed and the predicted concentration $\left(C_{\text {observed }^{-}}\right.$ $C_{\text {predicted }}$ ) can be used as the contribution from the unidentified source at the lower reach. Therefore, we obtained percent contribution from three sources to daily export on each sampling day. Figure 7 shows that the background and the upstream St. \#1 source contributed $31-61 \%$ and $2-43 \%$, respectively, to $\mathrm{NO}_{3}$ export under a range of discharge conditions. The percent contributions from these two sources increased with increasing water discharge rates (Figure 7). This is the feature seen for a diffuse source (Prochazkova et al., 1996). On the contrary, the contribution from the unidentified source below St. \#5 (0 to 70\%) showed an inverse correlation with water discharge showing its importance during the dry period. Our model results indicate that hydrological factors are important in regulating the relative contribution from three sources to total $\mathrm{NO}_{3}$ export. The importance of hydrology in determining $\mathrm{N}$ export from forested or mixed use watersheds has been emphasized previously (Prochazkova et al., 1996; Mitchell et al., 1996).

\subsection{DIN RETENTION IN NON-CULTIVATED SUB-WATERSHEDS}

The mean background DIN yield $\left(660 \pm 120 \mathrm{~kg} \mathrm{~N} \mathrm{~km}^{-2} \mathrm{yr}^{-1}\right)$ for the four tributaries was much higher than those for most pristine areas in the world (Lewis et al., 1999; Howarth et al., 1996). The current level of DIN atmospheric inputs is the most 
likely cause for the high background DIN yield. However, this reported atmospheric DIN input in northern Taiwan $\left(\sim 1800 \mathrm{~kg} \mathrm{~N} \mathrm{~km}^{-2} \mathrm{yr}^{-1}\right)$ is much higher than the background DIN yield. The sizeable difference between the atmospheric DIN input and background yield implies that a major fraction of atmospheric DIN inputs are retained or processed within the watershed.

For example, if atmospheric DIN inputs are $1800 \mathrm{~kg} \mathrm{~N} \mathrm{~km}^{-2} \mathrm{yr}^{-1}$, DIN retention is about $70 \%$. If $\mathrm{N}$ inputs from other sources such as $\mathrm{N}$-fixation and rock weathering (Holloway et al., 1998) were included, the proportion of $\mathrm{N}$ retention would increase. Our estimated retention is similar to that for many temperate forests but differs from that of tropical forests, which appear to have lower N retention (Bruijnzell, 1991; McDowell and Asbury, 1991).

Model estimates show that China is by far the largest source of $\mathrm{NO}_{\mathrm{x}}$ emissions in Asia (43\% of the total $\mathrm{NO}_{x}$ emission; Carmichael et al., 1993; van Aardenne et al., 1999; Streets and Waldhoff, 2000) and $\mathrm{NO}_{x}$ emissions in China are expected to show a 4\% increase per year (Carmichael et al., 1993; van Aardenne et al., 1999). The East-Asia region also has the largest amount of $\mathrm{NH}_{3}$ volatilized from agricultural upland in the world $\left(6189 \mathrm{~kg} \mathrm{~N} \mathrm{~km}^{-2} \mathrm{yr}^{-1}\right.$; derived from Bouwman et al., 2002). Several studies have demonstrated that considerable amounts of mineral aerosols and pollutants (e.g. $\mathrm{NH}_{4}$ and $\mathrm{SO}_{4}$ ) can also be transported, particularly in winter and spring, from the east coast of China to the North Pacific Ocean (Prospero et al., 1985; Uematsu et al., 1993) and to Taiwan (Hsu et al., 2003). The path of air parcels has been elucidated by air mass back trajectory analysis (Liu et al., 1996). Even two remote islands, Pengchiayu (Figure1b; unpublished data, S.-C. Hsu personal communication) and Penghu (Figure1b, data from Chen et al., 1998), which are located $50 \mathrm{~km}$ north and $30 \mathrm{~km}$ west of Taiwan island, receive high atmospheric DIN inputs of $>1500 \mathrm{~kg} \mathrm{~N} \mathrm{~km}^{-2} \mathrm{yr}^{-1}$, illustrating the scale of influence. Given the geographic location of Taiwan, i.e., the short distance $(\sim 100 \mathrm{~km})$ to the source region and a short travel time for air parcels from China to Taiwan (2-3 days or less; Central Weather Bureau Taiwan), forest ecosystems in Taiwan may receive increasing atmospheric DIN inputs. Long-term monitoring will be needed to evaluate other factors, such as vegetation cover (Kopacek et al., 1995) and lithology, governing watershed responses to increasing $\mathrm{N}$ inputs from both local and regional sources.

\section{Conclusions}

Local agricultural activity appears to have significant influence on spatial patterns of $\mathrm{NO}_{3}$ concentration and yields but has an insignificant effect on that of $\mathrm{NH}_{4}$ and $\mathrm{NO}_{2}$ concentrations. The positive relationship between $\mathrm{NO}_{3}$ concentration and water discharge rate suggested a flushing response to greater hydrologic flow in both cultivated and non-cultivated areas. Water runoff is the major factor determining total DIN export and regulating the relative contribution from three distinct sources to total $\mathrm{N}$ export. During flood periods, the background source 
and cultivated upstream point source dominated the DIN flux. On the contrary, the lower reach floodplain is the main contributor during low water discharge periods. On an annual basis, the upstream agricultural source, background, and the down stream floodplain contributed 25,51 and $24 \%$ to the total DIN export, respectively. Elevated atmospheric DIN input is likely responsible for the high background DIN yield $\left(660 \pm 120 \mathrm{~kg} \mathrm{~N} \mathrm{~km}^{-2} \mathrm{yr}^{-1}\right)$. However, much higher atmospheric DIN input suggests that $\sim 70 \%$ of input is retained or processed within the Lanyang-Hsi watershed. Long-term monitoring is needed to evaluate the potential impacts from increasing atmospheric DIN deposition.

\section{Acknowledgments}

This study was supported by grant (NSC 92-2116-M-001-019) from the Natural Science Council of Taiwan, ROC. We thank Prof. K. K. Liu and S. C. Pai (National Taiwan University) for useful comments and H. I. Lin for laboratory help.

\section{References}

Bashkin, V. and Park, S.-U.: 1998, Acid Deposition and Ecosystem Sensitivity in East Asia, Nova Science Publishers, Hauppauge, NY, 423 pp.

Bouwman, A.F., Boumans, L.J.M. and Batjes, N.H.: 2002: 'Estimation of global $\mathrm{NH}_{3}$ volatilization loss from synthetic fertilizers and animal manure applied to arable land and grasslands', Global Biogeochem. Cy. 16(2), doi: 10.1029/2000GB001389.

Bruijnnzel, L.A.: 1991, 'Nutrient input-output budgets of tropical forest ecosystems: A review', $J$. Trop. Ecol. 7, 1-24.

Burt, T.P., Arkell, B.P., Trudgill, S.T. and Walling, D.E.: 1988, 'Stream nitrate levels in a small catchment in south-west england over a period of 15 years (1970-1985)', Hydrol. Process. 2 , 267-284.

Carmichael, G.R., Amann, M., Azimi, A., Hbattcharya, S.C., Shrestha, R.M., Chadwick, M., Kuylenstierna, J., Cinderby, S., Foell, W., Green, C., Hettelingh, J.P., Hordijk, L., Shah, J., Singh, M., Street, D., Bhatti, N. and Zhao, D.: 1993, 'Acid rain and emissions reduction in Asia', Proceedings of the International Conference on Regional Environment and Climate Changes in East Asia, pp. 328-333.

Chen, Z.S., Liu, J.C. and Cheng, C.Y.: 1998, 'Acid deposition effects on the dynamic of heavy metals in soils and their biological accumulation in the crops and vegetables in Taiwan', in V. Bashkin and S.U. Park (eds.), Acid Deposition and Ecosystem Sensitivity in East Asia, Nova Science Publishers, Hauppauge, NY, pp.188-225.

Downing, J.A., McClain, M., Twilley, R., Melack, J.M., Elser, J., Rabalais, N.N., Lewis Jr, M., Turner, R.E., Corredor, J., Soto, D., Yanez-Arancibia, A., Kopaska, J.A. and Howarth, R.W.: 1999, 'The impact of accelerating land-use change on the $\mathrm{N}$-cycle of tropical aquatic ecosystems: Current conditions and projected changes', Biogeochemistry 46, 109-148.

Galloway, J.N., Levy, H. and Kasibhatia, P.S.: 1994, 'Year 2020: Consequences of population growth and development on deposition of oxidized nitrogen', Ambio 23, 120-123.

Galloway, J.N., Schlesinger, W.H., Levy, H., Michaels, A. and Schnoor, J.L.: 1995, 'Nitrogen fixation: Atmospheric enhancement-environmental response', Global Biogeochem. Cy. 9, 235-252.

Goan, L.H. and Chen, J.S.: 1995, The Third Forest Resources and Land Use Inventory in Taiwan, Forestry Bureau, Taipei, Taiwan. 258 pp. 
Ho, C.S.: 1975, An Introduction to the Geology of Taiwan, The Ministry of Economic Affairs, The Republic of China, 153 pp.

Holloway, J.M., Dahlgren, R.A., Hansen, B. and Casey, W.H.: 1998, 'Contribution of bedrock nitrogen to high nitrate concentrations in stream water', Nature 395, 785-788.

Howarth, R.W., Billen, G., Swaney, D., Townsend, A., Jaworski, N., Lajtha, K., Downing, J.A., Elmgren, R., Caraco, N., Jordan, T., Berendse, F., Freney, J., Kuderyarov, V., Murdoch, P. and Zhaoliang, Z.: 1996, 'Regional nitrogen budgets and riverine $\mathrm{N}$ and P fluxes for the drainages of the North Atlantic Ocean: Natural and human influences', Biogeochemistry 35(1), 75-140.

Hsu, S.C., Lin, F.J., Wu, C.H., and Jeng, W.L.: 2003, 'A new insight into the significance of aeolian dust particle inputs for sediment budgets in the East China Sea', Geophys. Res. Lett. (in review).

Jordan, T.E., Correll, D.L. and Weller, E.W.: 1997, 'Effects of agriculture on discharges of nutrients from coastal plain watersheds of Chesapeake Bay', J. Environ. Qual. 26, 836-848.

Kao, S.J.: 1995, 'The biogeochemistry of carbon on an island of high denudation rate: A case study of the Lanyang-Hsi watershed', Ph.D. Thesis, Institute of Oceanography, National Taiwan University, $262 \mathrm{pp}$.

Kao, S.J. and Liu, K.K.: 1996, 'Particulate organic carbon export from a subtropical mountainous river (Lanyang-Hsi) in Taiwan', Limnol. Oceanogr. 41, 1749-1757.

Kao, S.J. and Liu, K.K.: 2000, 'Stable carbon and nitrogen isotope systematics in a human disturbed watershed (Lanyang-Hsi) in Taiwan and the estimation of biogenic particulate organic carbon and nitrogen fluxes', Global Biogeochem. Cy. 14(1), 189-198.

Kao, S.J. and Liu, K.K.: 2002, 'Exacerbation of erosion induced by human perturbation in a typical oceania watershed: Insight from 45 tears of hydrological records from the Lanyang-Hsi River, Northeastern Taiwan', Global Biogeochem. Cy. 16(1), 10.1029.

King, H.B., Hsia, Y.J., Liou, C.B., Lin, T.C., Wang, L.J. and Hwong, J.L.: 1994, 'Chemistry of precipitation, throughfall, stem flow and streamwater of six forest sites in Taiwan' in Peng, C. I. and Chou, C.H. (eds.), Biodiversity and Terrestrial Ecosystem, Institute of Botany, Academia Sinica, Taiwan, pp. 355-362.

Kopacek, J., Prochazkova, L., Stuchlik E. and Blazka, P.: 1995, 'The nitrogen-phosphorus relationship in mountain lakes: Influence of atmospheric input, watershed, and $\mathrm{pH}$, Limnol. Oceanogr. 40(5), 930-937.

Kronvang, B., Grant, R., Larsen, S.E., Svendsen, L.M. and Kristensen, P.: 1995, 'Non-point-source nutrient losses to the aquatic environment in demark: Impact of agriculture', Mar. Freshwater Res. 46, 167-177.

Lin, T.C., Hamburg, S.P., King, H.B. and Hsia, Y.J.: 2000, 'Throughfall patterns in a subtropical rain forest of northeastern Taiwan', J. Environ. Qual 29, 1186-1193.

Liu, C.M., Young, C.Y. and Su, W.C.: 1996, 'Scenarios of $\mathrm{SO}_{2}$ and NOx Emission in TaiwanA review', Proceedings of International Conference on Acid Deposition in East Asia, Taipei, Taiwan, pp. 409-426.

Lewis, W.M., Melack, Jr. J.M., McDowell, W.H., McClain, M. and Richey, J.E.: 1999, 'Nitrogen yields from undisturbed watersheds in the Americas', Biogeochemistry 46, 149-162.

Mason, J.W., Wegner, G.D., Quinn, G.I. and Lange, E.L.: 1990, 'Nutrient loss via groundwater discharge from small watershed in south-western and south-central Wisconsin', J. Soil Water Conserv. 45, 327-331.

Matson, P.A., McDowell, W.H., Townsend, A.R. and Vitousek, P.M.: 1999, 'The globalization of N deposition: Ecosystem consequences in tropical environments', Biogeochemistry 46, 67-83.

McDowell, W.H. and Asbury, C.E.: 1991, 'Export of carbon, nitrogen, and major ions from three tropical Montane watersheds', Limnol. Oceanogr. 39(1), 111-125.

Meybeck, M.: 1993, 'C, N, P and S in rivers: From sources to global inputs', in R. Wollast et al. (eds.), Interactions of $C, N, P$ and $S$ Biogeochemical Cycles and Global Change, Springer-Verlag, New York, pp. 163-195. 
Meybeck, M., Chapman, D. and Helmer, R.: 1989, 'Global freshwater quality - A first assessment', WHO/ UNEP-GEMS Report, Oxford, Blackwell.

Milliman, J.D.: 1991, 'Flux and fate of fluvial sediment and water in coastal seas', in R.F.C. Mantoura et al. (eds.), Ocean Margin Processes in Global Change, Wiley, New York, pp. 69-89.

Mitchell, M.J., Driscoll, C.T., Kahl, J.S., Likens, G.E., Murdoch, P.S. and Pardo, L.H.: 1996, 'Climatic control of nitrate loss from forested watersheds in the northeast United States', Environ. Sci. Technol. 30, 2609-2612.

Ohrui, K. and Mitchell, M.J.: 1997, 'Nitrogen saturation in Japanese forested watersheds', Ecol. Appl. 7(2), 391-401.

Pai, S.C., Yang, C.C. and Riley, J.P.: 1990, 'Formation kinetics of the pink azo dye in the determination of nitrite in natural waters', Anal. Chim. Acta. 232, 245-249.

Parker, G.G.: 1983, 'Throughfall and streamflow in the forest nutrient cycle', Adv. Ecol. Res. 13, 57-133.

Pekarova, P. and Pekar, J.: 1996, 'The impact of land use on stream water quality in Slovakia', $J$. Hydrol. 180(1-4), 333-350.

Prochazkova, L. and Brink, N.: 1991, 'Relations between element-concentrations and water discharge in agricultural basins', CATENA 18, 355-366.

Prochazkova, L., Blazka, P, and Kopacek, J.: 1996, 'Impact of diffuse pollution on water quality of the Vltava River (Slapy Reservoir), Czech Republic', Water Sci. Technol. 33(4-5), 145-152.

Prospero, J.M., Savoie, D.L., Nees, R.T., Duse, R.A. and Merrill, J.: 1985, 'Particulate sulfate and nitrate in the boundary layer over the North Pacific Ocean', J. Geophys. Res. 90(10), 586-596.

Prospero, J.M., Barrett, K., Church, T., Dentener, F., Duce, R.A., Galloway, J. N., Levy, H., Moody, J. and Quinn, P.: 1996, 'Atmospheric deposition of nutrients to the North Atlantic Basin', Biogeochemistry 35, 27-73.

Schindler, D.W. and Bayley, S.E.: 1993, 'The biosphere as an increasing sink for atmospheric carbon: Estimates from increasing nitrogen deposition', Global Biogeochem. Cy. 7, 717-734.

Shiah, F.K., Kao, S.J. and Liu, K.K.: 1996, 'Spatial variability of phytoplankton production and the implications of its controlling mechanisms in the coastal zone near the river mouth of LanyangHsi', Bot. Bull. Acad. Sinica 37, 9-15.

Streets, D.G. and Waldhoff.: 2000, 'Present and future emissions of air pollutants in China: $\mathrm{SO}_{2}, \mathrm{NO}_{x}$ and CO', Atmos. Environ. 34, 363-374.

Strickland, J.D. and Parsons, T.R.: 1972, A practical handbook of seawater analysis, Bull. Fish. Res. Board. Can., 147, 311.

Taiwan Hydrological Yearbooks. 1970-2001. Water Resources Bureau, Ministry of Economic Affairs, Taiwan.

Uematsu, M., Komai, N., Medvedev, A.N. and Anikiev, V.V.: 1993, 'Long-scale transport of pollution aerosol over and deposition to the East Coast of Asia', Proceedings of the International Conference on Regional Environment and Climate Change in East Asia, pp.7-77.

van Aardenne, J.A., Carmichael, G.R., Levy H., Streets, D. and Hordijk, L.: 1999, 'Anthropogenic $\mathrm{NO}_{x}$ emissions in Asia in the period 1990-2020', Atmos. Environ. 33, 633-646.

Vitousek, P.M., Aber, J., Bayley, S., Howarth, R., Likens, G., Matson, P., Schindler, D., Schlesinger, W. and Tilman, D.: 1997, 'Human alteration of the global nitrogen cycle: Causes and consequences', Ecol. Appl. 7, 737-750. 